\title{
Thoughts and Exploration of Online College English Teaching in the Context of "Corona Virus Disease 2019" Epidemic
}

\author{
Wei Yang ${ }^{1, *}$
}

${ }^{1}$ The Tourism College of Changchun University, Changchun, Jilin 130607, China

"Corresponding author. Email: 474644277@qq.com

\begin{abstract}
During the "Corona Virus Disease 2019" (COVID-19) epidemic prevention and control period, the Ministry of Education proposed that colleges and universities as well as primary and middle schools in various places postpone the opening date of spring semester and use the online platform to carry out "non-stop learning during the suspending classes period". The education system is acting from top to bottom, taking the initiative to turn the pressure of the epidemic on education and teaching into a driving force for the reform and construction of education and informationization. This article combines the characteristics of online teaching in the context of the epidemic situation and The Tourism College of Changchun University's practical experience in developing online college English teaching, analyzes the challenges faced by online college English teaching, explores the implementation strategies of online college English teaching and reflects on the effects of this teaching mode, hoping to come up with some suggestions for online teaching of college English in special period.
\end{abstract}

Keywords: epidemic prevention and control, "non-stop learning during the suspending classes period",

college English, online teaching

\section{INTRODUCTION}

In December 2019, COVID-19 infection occurred in Wuhan and other places in Hubei province, and spread to the whole country. Today, there are more than 100 countries and regions affected by COVID-19 in the world, and WHO has raised the risk level of COVID-19 to "very high". At present, the COVID-19 is still unknown, which not only threatens people's health and life safety, seriously affects people's life and economic development, but also brings severe challenges to education. During the prevention and control of the epidemic, China has taken resolute and powerful prevention and control measures. In order to stop the epidemic from spreading to the campus and protect the health and safety of teachers and students, on January 27, 2020, the Ministry of Education issued a notice asking colleges and universities and primary and middle schools to postpone the spring start time. Students should be at home instead of going out; they shouldn't get together, organize or participate in concentrated activities. And the specific school start times have to wait for notice from education

*Fund: Jilin Province's Higher Education Research Project (JGJX2019D570) in 2019; 2018 Jilin Province Education Department Vocational Education and Adult Education Teaching Reform Research Project (2018ZCY352) administrations. The Ministry of Education also issued an initiative on January 29: to use online platforms to carry out "non-stop learning during the suspending classes period".

Jilin province actively responded to the Ministry of Education's call for "non-stop learning during the suspending classes period" during the epidemic prevention and control, and quickly launched online teaching guidance and programs. The Tourism College of Changchun University resolutely implements the instructions of the state and Jilin province, adheres to the principle of "non-stop teaching and non-stop learning during the suspending classes period" and has formulated the "Teaching Work Plan for the Postponement of the Spring Semester of 2020". The school also made overall adjustments to the teachingrelated work arrangements for the spring semester of 2020 to ensure the smooth implementation of teaching work. In the face of the epidemic, the education system is operating from the top to bottom. How to better carry out online teaching and make it more effective in special times is the main problem faced by education. 


\section{Challenges FACED BY ONLINE COLLEGE ENGLISH TEACHING DURING EPIDEMIC PREVENTION AND CONTROL}

First, online teaching is a challenge to the curriculum. Online teaching is not a simple space transfer problem. It will move the teaching scenario and teaching content in the classroom from the classroom to the Internet. Online teaching is not just a network broadcast. It is not as simple as a teacher giving a lecture to a computer screen. Students use a computer screen as a teacher and take notes while taking lessons. Online teaching is not that teachers blindly present students with a variety of online teaching resources without thinking and choosing. The method and content of college English online teaching need to be individualized and diversified, and its connotation should be more abundant.

Second, online teaching is a challenge for teachers. In the special context of the epidemic, all courses are converted to online courses, and teachers need to complete a large number of courses online in a short period of time. Especially for older teachers, it is a great challenge to learn and operate distance learning software that is not familiar to them in a short time. In addition, when teachers and students can't communicate face-to-face at this stage, whether teachers can control the teaching at a macro level, accurately grasp the teaching progress and the rhythm of students' online discussions, and effectively guide and feedback students' performance will all affect the effect of online college English teaching.

Third, online teaching is a challenge for students. During the epidemic prevention and control period, students can study at home. In order to ensure the learning effect, in addition to the tacit cooperation of schools, teachers, students, and parents, the most important thing is that students should give full play to their initiative and actively participate in online teaching. This is a test of students' ability to supervise and manage themselves. In addition, affected by factors such as geographical location, economic conditions, and family environment, whether students have smooth network support, whether they have advanced electronic equipment such as computers and mobile phones, and whether they have relatively independent, quiet, and comfortable learning spaces, will all affect learning effects of students.

\section{EXPLORATION ON ONLINE COLLEGE ENGLISH TEACHING DURING EPIDEMIC PREVENTION AND CONTROL}

During the period of epidemic prevention and control, although there are many challenges in carrying out "non-stop learning during the suspending classes period" college English online teaching, it also ushers in rare development opportunities. On February 5, 2020, the Ministry of Education specifically issued a notice on "Doing a Good Job in the Organization and Management of Online Teaching in Colleges and Universities During the Epidemic Prevention and Control", requiring universities to make full use of high-quality curriculum resources and teaching platforms to actively carry out online teaching and to open more than 24,000 online courses to universities nationwide for free so as to ensure teaching progress and teaching quality during epidemic prevention and control. In addition, a large number of nongovernmental online education-related institutions such as MOOC of Chinese university, CNMOOC, XuetangX, Wisdom Tree and Excellent Class Alliance have also opened online courses or other educational resources to the whole society. The opening of these teaching platforms and curriculum resources provides a strong guarantee for the smooth development of online teaching.

\section{A. Preparation for online college English teaching}

According to the unified deployment of the Ministry of Education and the Provincial Department of Education, the school has delayed the start of the spring semester of 2020, carefully planned and arranged in advance, formulated various work plans, made arrangements and requirements for specific work, and actively turned the pressure of the epidemic on education and teaching into a driving force for the reform and construction of education and informationization. In order to fully prepare for the comprehensive launch of online college English teaching on March 2, the leaders and teachers of the College English Teaching and Research Office of the Ministry of Basic Education have made various efforts.

Firstly, teachers update teaching concepts, determine teaching goals and formulate teaching plans based on the characteristics of online teaching in the context of epidemics.

Secondly, teachers combine the actual teaching of college English courses needs to select a suitable teaching platform and actively explore an efficient online teaching mode that suits the needs of teachers and students.

Thirdly, teachers quickly learn and master the theoretical knowledge and technical skills related to online teaching, and fully tap the technical advantages of online education. For example: how to carry out teaching activities through the online teaching platform; how to use the live broadcast platform to explain the teaching content; how to create a class QQ group or WeChat group to promote effective communication between teachers and students. 
Fourthly, teachers prepare teaching materials and design teaching content. Teachers can take full advantage of the shared and open quality course resources, or build their own course resources.

Fifthly, teachers re-examine and correctly look at the value of online education, and adhere to the original intention of teaching and educating people.

In the special period, many parties make concerted efforts and unite as one to complete all preparations for online college English teaching with guaranteed quality and quantity.

\section{B. Implementation of online college English teaching}

1) Online college English teaching model: During the epidemic prevention and control period, online teaching for university teachers and students mainly includes the following three modes: online courses, online live teaching, and television air class. Among them, online courses and online live teaching refer to the use of Internet technology to break through the constraints of time and space, relying on the network, digital terminals, network platforms and resources so as to achieve a new teaching mode for teachers and students in different places. The television air class was born in 2003 during the SARS period. It is a distance education teaching model based on digital television and broadcasting, which had played a huge role during the SARS period. At present, in the face of network congestion or in some remote areas, television air class will still play an important role.

The Tourism College of Changchun University has been conducting online teaching for two weeks. After exploration and practice, it has gradually formed a college English online teaching model that is mainly based on online courses and supplemented by online live teaching, which has both individuality and promotion value. Online college English teaching includes the following basic elements: digital terminal, network, network platform, curriculum resources, teachers and students. After investigation, teachers and students of The Tourism College of Changchun University have digital terminals such as computers and mobile phones, and the network is relatively smooth. In addition, teachers here make full use of high-quality online platforms and online course resources, such as Superstar Learning Link, Tencent Conference, and the matched MOOC teaching materials of FLTRP of UMOOCs to ensure the smooth development of online college English teaching. In addition, teachers establish a class QQ group and a class WeChat group in order to better strengthen communication, coaching and answering questions between teachers and students.
2) Establishing online gold courses based on the concept of "student-centered": The traditional "teachercentered" teaching model no longer meets the needs of modern English teaching, and the "student-centered" teaching model has gradually occupied a dominant position in China. In the "student-centered" classroom, students have the initiative to learn. Teachers guide and help students find and solve problems and form learning results in this process. And online teaching depends on students' autonomous learning consciousness and learning ability. Teachers need to cultivate and stimulate students' motivation for autonomous learning, and give more power to students' thinking, practice and feedback.

First of all, teachers define the teaching goals for the characteristics of online education, and determine teaching content suitable for students' online learning based on the teaching goals. Second, teachers need to prepare teaching resources. In special period, it is unrealistic for teachers to prepare lessons and immerse themselves in teaching resources as usual. Instead, they must maintain an active and open mind and actively pay attention to collecting and selecting online teaching resources that meet the needs of college English teaching. Of course, teachers can also process or make teaching resources on their own, including but not limited to PPT courseware, e-books, micro-video and other forms. What's more, teachers should focus on the design of resource-based teaching activities, provide students with driven learning tasks, and set up and push task points to students to urge them to complete course learning tasks. For example, teachers arrange topics for students through the online platform. Tasks can be submitted in various forms, such as micro-videos, and uploaded to the online platform for display and sharing so as to receive extensive evaluation and capture more ideas.

Through the network teaching platform, students can obtain learning resources for autonomous learning whenever and wherever possible, so as to build their own knowledge system. Teachers can perform class management behind the scenes, follow up and record every learning behavior of students, understand the learning progress and knowledge of each student, and perform real-time evaluation and statistics.

Teachers build online gold lessons based on the "student-centered" philosophy, turn online classrooms into a vibrant maker space and encourage students to share creative ideas. Students are no longer passive recipients of knowledge, which stimulates their enthusiasm and creativity.

3) Enhancing the interactivity of online teaching: Online live teaching is that teachers use software such as Tencent Conference to organize teaching directly to students on the network through live broadcast. 
Compared to online courses, teachers and students have a strong sense of presence in online live teaching and can achieve real-time interaction, which are closer to real offline classrooms. In addition, today, in the highly developed Internet, live broadcast industry and culture, online live teaching is more attractive to today's young people. Through research and practice, it has been shown that, as a direct and convenient teaching method, online live teaching is a good supplement and support to online teaching based on online courses, which is conducive to improving learning interaction and learning performance in online college English teaching. It should be noted that online live teaching is only part of online teaching. It is a mistake to understand online teaching simply as letting teachers act as "anchors" in front of cameras.

\section{Feedback on the effect of online college English teaching}

In order to ensure the quality of online teaching in college English, the College English Teaching and Research Office of the Ministry of Basic Education has separately produced questionnaires for the online teaching of teachers and students to investigate the operation of teaching and the effects of teaching. As of March 15 (two weeks after the start of the course), a total of 61 teachers and 3,050 students participated in the questionnaire survey. The survey results show that $90 \%$ of teachers are satisfied with or above the overall evaluation of online teaching, and $92 \%$ of students are satisfied with or above the overall evaluation of online teaching. At the same time, the survey results show that online courses and online live teaching, mainly used in online college English teaching, have both advantages and disadvantages. For example, online courses are mostly courses designed by outstanding teachers. The teacher's teaching level is first-rate, and the teaching content is rich and diverse, which stimulates students' learning interest. The course has a "playback" function, and students can consolidate repeatedly; the learning time is free and flexible. But the main disadvantage is that teachers and students can't communicate face to face, and the interaction effect is poor. Online live teaching can make teachers and students have a one-toone teaching experience, which makes up for the emotional lack of online teaching to a certain extent, but the main problem is that it requires high network environment and is prone to Internet lag.

Therefore, it is recommended that teachers adopt the idea of online flipped classroom. Students first learn online courses, and then teachers discover common problems of students through exercises, arranging course learning tasks, quizzes, etc. Teachers will make a breakthrough at key points in the way of live teaching to answer questions for students. In the special context of the epidemic, "staggering peak live broadcast" can be implemented. Only by organically combining the two and complementing each other's advantages can good results be got. During the epidemic prevention and control period, teachers and students face challenges and difficulties together, and are confident and capable of carrying out online college English teaching.

There are differences in the level of development of education informatization, the basic conditions of informatization in schools, and the quality of teachers. The online teaching programs adopted may be different. Therefore, various regions need to formulate online teaching models, strategies and methods of college English that meet their own development needs based on actual conditions.

\section{CONCLUSION}

The outbreak of the epidemic has had an impact on traditional education, but at the same time it has also stimulated the vitality of online education and promoted the reform and innovation of college English teaching. In special period, the advantages of online teaching are prominent, such as: teaching breaking through the time and space limitation, sharing high-quality educational resources, etc., its advanced nature, scientificity and practicality are self-evident. During the epidemic prevention and control period, online teaching of "nonstop learning during the suspending classes period" not only ensures the safety of teachers and students, but also meets the needs of national education development and the growth of teachers and students. However, in practice, it is found that online teaching inevitably expose some problems. Therefore, it is necessary to view the value of online teaching correctly and objectively, and use online teaching as a supplement and promotion of offline teaching. In fact, whether it is online teaching, offline teaching or online and offline mixed teaching, grasping the basic concept of "studentcentered" so that students learn independently, think hard, take delight in exploring and dare to practice is the goal teachers want to achieve.

\section{References}

[1] Ministry of Education. Notice of the Ministry of Education on Delaying the Start of Spring Semester in 2020 [EB / OL] Http://www.moe.gov.cn/jyb_xwfb/gzdt_gzdt/s5987/202001/t20 200127_416672.html, 2020-01-27. (in Chinese)

[2] Ministry of Education. Ministry of Education: Using the internet platform, "Non-stop Learning During the Suspending Classes Period" [EB / OL] Http://www.moe.gov.cn/jyb_xwfb/s5147/202002/t20200203_41 7488.html, 2020-01- 29. (in Chinese)

[3] Jiao Jianli, Zhou Xiaoqing, Chen Zexuan. A Case Study of Online Teaching of "Non-stop Learning During the Suspending Classes Period" Against the Background of Epidemic Prevention and Control [J]. China Educational Technology, 2020: 106-113. (in Chinese) 
[4] Wang Yunwu, Wang Yuru, Li Yanxin, Li Dan. Countermeasures and suggestions to improve the quality of online education during epidemic prevention and control [J]. China Medical Education Technology, 2020. (in Chinese)

[5] Lyu Haixia, Wang Yuan, Liu Wenbin, Lyu Yi, Yan Hong. Challenge and Strategy for PBL Teaching Activities during Prevention and Control of COVID-19 [J]. Medical Education Research and Practice, 2020. (in Chinese)

[6] Liu Li. The Investigation on Learning Strategies of College English under the Background of "Novel Coronovirus Epidemic" [J]. Journal of Tonghua Normal University, 2020. (in Chinese) 